\title{
Memories of the ANU Historical Journal
}

Caroline Turner

ANUHJ Editor, 1966-68

When I started to think about my memories of the $A N U H J$ in the late 1960s, the first people who came to mind were Anne Kingston and Margaret George. Talented and inspiring young historians, Anne and Margaret played leading roles in the formation and early life of the ANU Historical Society and the Journal. Both later pursued postgraduate research at The Australian National University (ANU) in then emerging historical fields: American history and Australian diplomatic history related to Indonesia, respectively. Both also sadly died very young: Anne aged 25 in 1968, and Margaret aged 28 in 1974.

An essay by Anne, titled 'The Negro in Colonial New York, 1664-1776', was published posthumously in the ANUHJ in 1968. Ken Inglis described Anne's pivotal role in founding the Journal in the same issue. He also noted that Anne's MA would have been the first completed thesis in American history at ANU and resulted from her commitment to explore issues of 'justice and injustice, hatred and compassion'. ${ }^{1}$ When I came to ANU as an undergraduate in 1966, I knew Anne as the founder of the Journal (with Ron Fraser and Alastair Davidson) and I remember her speaking at one of the Society meetings. She was, as Manning Clark wrote, someone who drew people to her. ${ }^{2}$

Margaret George's PhD, undertaken in the Research School of Pacific Studies at ANU, was awarded posthumously in 1974. It was published by Melbourne University Press in 1980 under the title Australia and the Indonesian Revolution and is considered an important contribution to the history of Australia's relations with one of our nearest neighbours. ${ }^{3}$

1 KS Inglis, 'Anne Fraser', ANU Historical Journal, no. 5 (1968), 5-6.

2 Manning Clark, 'Anne Fraser', ANU Historical Journal, no. 5 (1968), 6.

3 Margaret George, Australia and the Indonesian Revolution (Melbourne: Melbourne University Press in association with the Australian Institute of International Affairs, 1980). 
I remember Margaret as an extremely generous mentor who encouraged me as a 'fresher' undergraduate straight from high school. Margaret was a key member of the Journal's editorial committee from 1966 to 1967. We remained friends and I visited her when I went overseas to undertake postgraduate research. She was then in the Netherlands researching Dutch-Indonesian relations between 1945 and 1949, having learned Dutch to do so. ${ }^{4}$ She was always enthusiastic and optimistic about the significance of history in comprehending the challenging questions of our times.

Although Anne and Margaret came immediately to mind, there are many others I remember in relation to the Journal and the Society-too many to name here, but who included Ron Fraser, Jill Waterhouse (before she went to study at Cambridge), Penny Joy, Rosemary Auchmuty, Iain McCalman (who I later worked with at the ANU Humanities Research Centre when he was Director there and I was Deputy Director), John Darling, Ian Britain, Helen McCallum, John Iremonger, Bill Garnett, Gerald Garnett and Martin Gascoigne (whose mother, Rosalie Gascoigne, was the first female artist to represent Australia at the Venice Biennale in 1982).

I served on the editorial committee for the $A N U H J$ for three years from 1966 to 1968, and my first publication was in the 1970 issue. My main memories of the editorial committee - very much a student-run initiative with a strong undergraduate involvement-are of its inclusiveness. I recall meetings of the committee held in Margaret George's room at Bruce Hall and one held outdoors in the warm sunshine of a Canberra spring at John Iremonger's house near the campus, where we all sat on the lawn and discussed the submitted essays. John, a postgraduate student, helped establish Australian National University Press in 1967 and later his own press. Other students brought publishing experience. Penny Joy, an honours student in history, worked on both the student newspaper Woroni and Aboriginal Quarterly.

The context in which the Journal was created and existed was a period when Australian society and universities were undergoing fundamental change. Demographic change was underpinned by new immigrants in the postwar years, many from Europe rather than Britain. Although many students were the first generation in their family to go to university, this

4 'Dr Margaret Lorraine George (1945-74)', National Archives of Australia, accessed at www.naa. gov.au/about-us/grants/margaret-george/bio.aspx. 
was becoming an aspiration for the baby boomer generation. While the student population was still small, students in the 1960s came to ANU from all over Australia and the world. For example, my husband, Glen Barclay, came from the New Zealand Treasury to do a PhD in the early 1960s. ANU in the mid-1960s was expanding rapidly. SG Foster and Margaret Varghese note that in 1961, one year after the Canberra University College amalgamated with ANU, there were 948 undergraduates, mostly parttime public servants. The ratio of men to women students was then three to one. By 1965, there were 2,387 undergraduates and those who were full-time (mostly in the 17-21 age group) for the first time outnumbered the generally older part-time students. There were more women, although men were still the majority. ${ }^{5}$

From the mid-1960s the numbers of undergraduates studying history grew substantially. History began to reflect changes in the contemporary world-the popularity of American history, for example, was a direct reflection of the growing significance of the US in Australian politics and culture in the postwar era. Asian history, Indigenous history and later, in the 1970s, women's studies also began to be part of courses. Manning Clark was a major influence in the growing field of Australian history and also open to new histories. ${ }^{6}$ Manning was part of the cultural delegation I led to China in 1984 when I was a member of the Australia-China Council (the Australian Government body devoted to developing cultural relations with China). His short history of Australia had been translated into Chinese and was in use in university classes there and it was fascinating watching Manning lecture to Chinese students who, at the time, wore Mao suits. I mention this later trip to China because it illustrates something of the sense of discovery we felt in pioneering new ways of thinking about Australia and Australian history, including Australia's history and place in the Asia-Pacific region, a concept that became part of our thinking in the era in which the first series of the $A N U H J$ was published.

5 SG Foster and Margaret M Varghese, The Making of The Australian National University (Canberra: ANU E Press, 2009), 197-98.

6 Manning and his wife Dymphna, the latter an impressive linguist, generously invited honours students to their Robin Boyd-designed home in Forrest and house at the coast. 
Australian history as a discipline expanded its parameters to take account of demographic and geopolitical changes in the 1960s. Our knowledge of Aboriginal culture and thus of Australian history was also being dramatically reshaped in the late 1960s by archaeological discoveries by Professor John Mulvaney and others.

My main field of study was American history. The early issues of the $A N U H J$ published several articles in this area, especially relating to black history in the context of the US civil rights movement, which had inspired many of us. We were also aware of the important role ANU played as a newly founded centre for Asian and Pacific studies with students coming from around Australia to study Asian languages and history. Professor Wang Gungwu, who had been appointed to the Chair of Far Eastern History at ANU in 1968, was a towering scholarly presence. The interest in Asia inspired by such scholars became an important part of my own world view. The $A N U H J$ did not immediately reflect this new interest in Asia, but there was an emerging appreciation in the late 1960s that we needed to know more about the histories, cultures and contemporary developments in the region in which Australia is geographically situated. Margaret George's interest in Indonesia was certainly my first exposure to the history of Indonesia - a country that later became very close to my heart in the 1990s when I was a member of the Australian Government's Australia-Indonesia Institute.

Students in the late 1960s at ANU were engaged in passionate debates, especially on current issues including the Vietnam War and Aboriginal rights. Conscription had been reintroduced in Australia in 1964 and in the following year overseas service in Vietnam was introduced for conscripts. Many of the men in our cohort at ANU had to go through conscription ballots. ${ }^{7}$ Demonstrations were held against the war, including on the occasion of President Lyndon Johnson's visit to Canberra in $1966 .{ }^{8}$ Many students, including myself, were also involved with demonstrations for Land Rights for Aboriginal people and in Abschol

7 The Australian War Memorial website states: 'From 1965 to 1972, 15,381 national servicemen served in the Vietnam War, with 200 killed and 1,279 wounded Nearly 60,000 Australians served in the Vietnam War'. 'National Service Scheme', Australian War Memorial, accessed at www.awm.gov. au/articles/encyclopedia/conscription/vietnam.

8 This was the occasion when ANU student Megan Stoyles wore the t-shirt reading 'Make Love not War', which became an international media sensation. See Megan Doherty, 'Fifty Years Since the Make Love Not War T-Shirt caused a stir around the world', Canberra Times, 19 October 2016, accessed at www.canberratimes.com.au/national/act/fifty-years-since-the-make-love-not-war-tshirtcaused-a-stir-around-the-world-20161019-gs5jcv.html. 
(Aboriginal Scholarships), which had begun in the 1950s as an initiative of the National Union of Australian University Students. In May 1967 over 90 per cent of Australians voted 'yes' in a constitutional referendum that paved the way for further rights for Aboriginal people. ${ }^{9}$ The ANU Chancellor HC Coombs was a major advocate for Indigenous rights and I remember Aboriginal poet Kath Walker (Oodgeroo Noonuccal) telling me of the importance of his work as a supporter of Indigenous organisations and in influencing government.

The years I was an undergraduate at ANU from 1966 also coincided with a move for university reforms - this was particularly so in 1968 and the themes of student revolutions in Europe were much discussed.

When I recently opened the box containing my copies of the ANUHJ, I also found a plastic badge with the initials 'CCUR', which stood for 'Coordinating Committee for University Reform'. The movement for university reform at ANU in the late 1960s consisted mostly of writing reports and meeting with senior staff including the Vice-Chancellor, Sir John Crawford (1968-73), who was supportive of students being involved in university planning. The more violent sit-ins and occupations, including the famous occupation of the Chancellery in 1974, occurred after Crawford left ANU.

The movement for reforms in terms of gender equality also began to gain momentum in the late 1960s. The presence of women in senior university positions was still a relatively recent phenomenon. Hanna Neumann had been appointed the first female professor at ANU, as Professor of Mathematics, in 1964. One inspiring female lecturer was Daphne Gollan in Russian history. Another was Beryl Rawson in the Classics department. ANU was not alone among universities in having fewer female role models for young women, but there was some improvement in the 1970s with the introduction of women's studies and momentum for societal reforms such as equal pay. ${ }^{10}$

9 This result allowed the Commonwealth to make laws for Aboriginal people. See Matthew Thomas, 'The 1967 Referendum', Parliament of Australia, accessed at www.aph.gov.au/About_Parliament/ Parliamentary_Departments/Parliamentary_Library/FlagPost/2017/May/The_1967_Referendum.

10 Ann Curthoys (who later held the Manning Clark Chair of History) and Susan Magarey founded the program. Magarey notes Daphne Gollan introduced her to the Canberra Women's Liberation group in 1970. See Ilona Wallace, 'Susan Magarey: Australian Feminism and Dangerous Ideas', Adelaide Review, 1 May 2015, accessed at www.adelaidereview.com.au/features/general/susanmagarey-women-studies-dangerous-ideas-profile-australia-feminism/. 
I recently discussed why history seemed such a relevant subject to study in the late 1960s with Penny Joy, who served on the editorial committee in 1968. As Penny stated, part of the reason history was deemed significant was because it was a way of making sense of a rapidly changing world, especially in the era of the Cold War. We both agreed that in the twentyfirst century, and especially in this current era of 'post-truth', people's historical awareness and knowledge of context and history is diminishing and serious research skills may be declining in the age of the internet. As Penny put it, this makes history journals such as the $A N U H J$ even more relevant today, especially if they deal with the importance of scholarly research. ${ }^{11}$

Caroline Turner completed her MA and $\mathrm{PhD}$ in History and is currently an Honorary Senior Fellow in the Humanities Research Centre (HRC), ANU, and Deputy Director of the ANU Indonesia Institute. Prior to joining the HRC in 2000 as Deputy Director she was Deputy Director of the Queensland Art Gallery and curated many international exhibitions, including co-founding the AsiaPacific Triennial of Contemporary Art. She has written extensively on art and society and been involved for over 40 years in Australia's international cultural relations/diplomacy. Her most recent book (with Jen Webb) is Art and Human Rights: Contemporary Asian Contexts, Manchester University Press, 2016.

11 Penny Joy in email correspondence to Caroline Turner on 30 May 2018. 
This text is taken from ANU Historical Journal II: Number 1, published 2019 by ANU Press, The Australian National University, Canberra, Australia.

doi.org/10.22459/ANUHJII.2019.03 